\title{
ANALISIS GAYA HIDUP (LIFESTYLE) SEBAGAI FAKTOR RESIKO PENYAKIT GAGAL GINJAL KRONIS
}

\author{
Diyono $^{1}$, Ratna Indriati ${ }^{2}$ \\ Penelitian Dosen Pemula \\ Dibiayai oleh Direktorat Riset dan Pengabdian Masyarakat (DRPM) \\ Kementrian Riset Teknologi dan Pendidikan Tinggi
}

\begin{abstract}
Background : globally, nationally, and regionally, chronic renal failure tends to increase. The most effective therapy for chronic renal failure is the prevention of risk factors. Objectives : identify lifestyles in the form of high-fat diet habits and consumption of energy supplements as a risk factor for chronic renal failure.

Methods : this research is a correlation research with case control design. The sample were 75 case study groups and 75 control groups. Data obtained through interviews and analyzed using multiple logistic regression with SPSS series 18.

Results : lifestyle that affect the incidence of chronic renal failure is high fat dietary habits $(p=0.001 ; O R=0.256 ; \mathrm{Cl}=0.116-0.562)$, consumption of energy supplements $(P=$ $0.001 ; \mathrm{OR}=0.229 ; \mathrm{Cl}=0.094-0.560$ ).

Conclution : research conclusions are high-fat dietary habits and consuming energy supplement drinks is a lifestyle that affects the increased risk of chronic renal failure.
\end{abstract}

Keyword: Chronic Kidney Desease, Lifestyle, Risk Factors.

\section{PENDAHULUAN}

Kejadian penyakit gagal ginjal kronis cenderung mengalami peningkatan. Diperkirakan insiden penyakit ginjal kronik tahap akhir di Indonesia adalah sekitar 30,7 per juta populasi dan prevalensi sekitar 23,4 per juta populasi. Pada tahun 2011 terdapat sekitar 10.000 orang yang menjalani terapi hemodialisa (IRR, 2011). Data dari Dinas Kesehatan Propinsi Jawa tengah tahun 2008, menunjukkan bahwa angka kejadian kasus gagal ginjal di Jawa Tengah yang paling tinggi adalah di Kota Surakarta dengan 1497 kasus (25.22 \%) dan diposisi kedua adalah Kabupaten Sukoharjo yaitu 742 kasus (12.50 $\%)$. Cuci darah merupakan terapi gagal ginjal pilihan utama, namun mempunyai dampak yang luas baik secara fisik, sosial dan ekonomi. Penelitian McKercher et al. (2013), membuktikan bahwa penyakit Chronic Kidney Desease mempengaruhi psikososial dan kecemasan pasien dan sebaliknya keadaan psikososial dan kecemasan pasien juga akan berpengaruh terhadap proses patologi penyakit Chronic Kidney Desease. Gagal ginjal kronis adalah penurunan atau hilangnya fungsi ginjal yang bersifat ireversibel yang ditandai kegagalan ginjal menjaga keseimbangan cairan, metabolisme dan elektrolit (Smeltzer dan Bare, 2010). Penyebab penurunan nefron dapat terjadi akibat penyakit sistemik seperti diabetus melitus, hipertensi, glumerulonefritis dan penyakit autoimun (William dan Hopper, 2003). Penelitian Chang et.al (2013) pada pasien yang mengikuti program Kidney Early Evaluation Program (KEEP) di National Kidney Foundation Miniapolis menunjukkan bahwa gaya hidup (lifestyle) sebagai faktor resiko gagal ginjal kronis tahap akhir (End Stage Renal Desease/ESRD) 
paling banyak karena penyakit diabetus melitus dan hipertensi dimana kedua penyakit tersebut terjadi karena gaya atau pola hidup yang tidak sehat. Hasil penelitian Ristienika tahun 2014 di RSUD Dr. Suroto Ngawi Jawa Timur juga memberikan bukti bahwa gaya hidup berupa kebiasaan mengkonsumsi minuman suplemen energi merupakan faktor resiko utama gagal ginjal kronis, selain merokok dan konsumsi kopi.

\section{TUJUAN PENELITIAN}

Penelitian bertujuan untuk menganalisis gaya hidup (lifestyle) kebiasaan konsumsi diet tinggi lemak dan minuman suplen energi sebagai faktor resiko penyakit gagal ginjal kronis

\section{METODE PENELITIAN}

Penelitian merupakan penelitian observasi analitik (analitic observasional) dengan desain case control, dilakukan dengan cara melakukan penelusuran gaya hidup 75 pasien gagal ginjal kronis dibandingkan dengan 75 responden sehat atau tidak terdiagnosa penyakit gagal ginjal kronis. Data dikumpulkan dengan pedoman wawancara dan dianalisa menggunakan uji regresi logistik ganda dengan bantuan program SPSS seri 18. Pengaruh dari masing - masing variabel ditentukan berdasar nilai $p$ (tingkat kemaknaan) dan nilai OR (odd rasio).

\section{HASIL PENELITIAN DAN PEMBAHASAN}

1. Karakterisitik Responden

Gambaran demografis secara umum responden, sebagaimana terlihat pada tabel 1 di bawah ini, terlihat berdasar jenis kelamin kedua kelompok baik kelompok kasus (sakit gagal ginjal) maupun kelompok kontrol (sehat) mempunyai persentase yang sama, yaitu laki - laki lebih banyak daripada perempuan yaitu $56.0 \%$ berbanding dengan $44.0 \%$. Umur paling banyak kelompok kasus usia 41- 60 tahun $(60 \%)$, sedang pada kelompok kontrol paling banyak usia lebih dari 60 tahun sebanyak $77.3 \%$.Data yang cukup menarik sesuai hasil penelitian ini adalah kelompok umur dari kelompok kasus yang mengalami gagal ginjal adalah pada umur produktif yaitu $20-40$ tahun yang mencapai $21.3 \%$ dan kelompok umur 41 - 60 tahun sebesar $60.0 \%$. Kondisi ini patut menjadi perhatian karena sesuai proses patologi penyakit gagal ginjal yang bersifat kronis progresif dan ireversibel, pada umumnya dapat mempengaruhi peran pasien secara sosial, ekonomi, maupun psikologi, bahkan juga fungsi dan proses dalam keluarga secara umum.

Tabel 1.

Karakteristik Responden

\begin{tabular}{lcc}
\hline Karakteritik & Kasus & Kontrol \\
\hline Jenis Kelamin & & \\
Laki-Laki & 42 & 42 \\
& 56.0 & 56.0 \\
Perempuan & 33 & 33 \\
& 44.0 & 44.0 \\
Agama & & \\
Islam & 64 & 49 \\
& 85.3 & 65.3 \\
Kristen & 4 & 7 \\
& 05.3 & 09.3 \\
Budha & 1 & 2 \\
& 01.3 & 02.7 \\
Katolik & 6 & 17 \\
& 08.0 & 22.7 \\
Umur & 16 & 0 \\
$20-40$ & 21.3 & 00.0 \\
& 45 & 17 \\
$41-60$ & 60.0 & 22.7 \\
& 14 & 58 \\
$>60$ & 18.7 & 77.3 \\
& &
\end{tabular}


2. Analisis Regresi Logistik Ganda Tabel 2.

Hasil Analisis Regresi Logistik Ganda dengan SPSS seri 18

\begin{tabular}{|c|c|c|c|}
\hline Variabel & $x^{2}$ & Sig. & $\operatorname{Exp}(B)$ \\
\hline $\begin{array}{l}\text { Tinggi } \\
\text { Lemak(1) }\end{array}$ & 0.001 & 0.001 & 0.256 \\
\hline $\begin{array}{l}\text { Suplemen } \\
\text { energi(1) }\end{array}$ & 0.001 & 0.001 & 0.229 \\
\hline Variabel & \multicolumn{3}{|c|}{ 95\% C.I.for EXP(B) } \\
\hline & \multicolumn{2}{|c|}{ Lower } & Upper \\
\hline TinggiLemak (1 & \multirow{2}{*}{\multicolumn{2}{|c|}{$\begin{array}{l}0.116 \\
0.094\end{array}$}} & 0.562 \\
\hline Suplemen(1) & & & 0.560 \\
\hline
\end{tabular}

Berdasar analisis multivariat dengan uji regresi logistik ganda sesuai tabel 2. maka dapat diuraikan sebagai berikut :

a. Pengaruh Kebiasaan Diet Tinggi Lemak Terhadap Gagal Ginjal Kronis

Hasil penelitian menunjukkan gaya hidup atau lifestyle diet atau konsumsi tinggi lemak paling berpengaruh terhadap peningkatan resiko penyakit gagal ginjal kronis $(p=0.001 ; O R=0.256)$. Secara patofisiologis diet tinggi lemak tidak langsung menyebabkan gagal ginjal kronis, namun melalui perubahan patologis lain seperti diabetus, arteriosklerosis, hipertensi, gagal jantung dan penyakit pembuluh darah lainya (Reynard, Brewster, dan Biers, 2006). Konsep tersebut terbukti pada penelitian ini, dimana pasien yang mengalami gagal ginjal kronis sebagian besar mempunyai riwayat penyakit hipertensi $20.0 \%$ diabetus melitus $36,0 \%$, hipertensi dan diabetus melitus $18,7 \%$ dan yang tidak mempunyai riwayat penyakit sebanyak $25.3 \%$. Salah satu faktor resiko dari kerusakan nefron adalah jika terjadi penurunan suplay darah ke nefron sebagai akibat dari hipertensi, diabetus melitus, dan gagal jantung (Mahon, Karen, dan Lisa, 2013). Penumpukan lemak di daerah perut merupakan salah satu faktor risiko yang memicu timbulnya diabetes mellitus. Peningkatan penderita diabetes akan meningkatkan jumlah penderita penyakit ginjal akibat komplikasi dari diabetes yaitu nefropati diabetes (Cahyono, 2008).

b. Pengaruh Kebiasaan Minum Minuman Suplemen Energi

Konsumsi suplemen energi mempunyai pengaruh terhadap terjadinya penyakit gagal ginjal kronisp $=0.001 ; \mathrm{OR}=0.229 ; \mathrm{Cl}=0$ .094-0.560). Minuman suplemen energi mayoritas mengandung taurin (2 minoethanesulfonic Acid) yaitu asam amino yang berasal atau ada pada jaringan otot hewan yang berfungsi sebagai pemicu kelistrikan sel atau jaringan seperti otak, neuron, jantung dan sistem endokrin (Oja dan Saransaari, 2006). Taurin ditambah dengan vitamin $\mathrm{C}$ dan kafein akan merangsang sistem neuromodulator sehingga akan membuat sel dan jaringan otak akan selalu terjaga dan waspada, dengan melibatkan peningkatan denyut jantung dan sistem sensori. Dengan kata lain zat tersebut akan membuat individu yang mengkonsumsinya akan tetap merasa tidak lelah, tidak mengantuk dan energi yang cukup untuk beraktivitas. Karena tidak merasa lelah maka membuat organ tubuh 
selalu aktif dan lebih cepat mengalami aus atau kerusakan. Gagal ginjal merupakan proses patologi yang tidak bersifat akau atau mendadak, melainkan terjadi dalam waktu yang lama tetapi berkembang makin lama makin memburuk (progresif destruktif). Dalam minuman suplemen energi rata-rata dalam 1 (satu) botol mengandung taurin 1000 $2000 \mathrm{mg}$. Pada dasarnya taurin mempunyai efek stimulan terhadap otak dan otot, namun jika zat tersebut dicampur dengan kafein atau alkohol maka dapat memberikan efek yang berlebihan sehingga mempercepat kerusakan selsel yang ada dalam tubuh termasuk nefron sebagai unit fungsional ginjal. Apalagi jika zat ini dikonsumsi dalam waktu yang lama dan sering, maka dampak kerusakan ginjal.

Hasil penelitian ini mirip dengan hasil penelitiaan Delima (2014) yang menunjukkan bahwa konsumsi minuman berenergi dan bersoda meningkatkan resiko gagal ginjal kronis sebesar 1,56 - 9,37 kali dibanding individu yang tidak mengkonsumsi. Hasil penelitian Hidayati, Haripurnomo, dan Suhardi (2008) juga hampir sama, dimana konsumsi minuman suplemen meningkatkan resiko gagal ginjal kronis 6,63 kali. Penelitian lain yang dilakukan pada hewan percobaan yaitu dengan pemberian minuman suplemen energi pada tikus memnunjukkan bahwa tingkat kelelahan akibat aktivitas (berenang dan loncat) lebih banyak terjadi pada kelompok tikus yang diberi minuman suplemen energi. Hal ini bukan berarti minuman suplemen energi baik untuk aktivitas, namun tikus tidak mampu mengontrol aktivitas dan kelelahan yang dapat merusak organ jantung dan ginjal (Herwana,et.al, 2005).

\section{KESIMPULAN}

Gaya hidup (lifestyle) yang berpengaruh terhadap peningkatan resiko penyakit gagal ginjal kronis adalah diet tinggi lemak dan kebiasaan mengkonsumsi minuman suplemen energi.

\section{SARAN}

1. Perawat dalam memberikan pendidikan kesehatan tentang pencegahan penyakit gagal ginjal kronis, diharapkan dapat menjelaskan bahwa kebiasaan diet tinggi lemak dan mengkonsumsi minuman suplemen energi dapat meningkatkan resiko terkena penyakit gagal ginjal kronis.

2. Rumah sakit dan fasilitas kesehatan lainya diharapkan dapat membuka layanan konsultasi tentang cara pencegahan dan deteksi dini penyakit gagal ginjal kronis.

3. Untuk peneliti selanjutnya diharapkan dapat melakukan penelitian yang lebih komprehensif tentang faktorfaktor lain yang mempengaruhi kejadian penyakit gagal ginjal kronis, misalnya faktor penyakit hipertensi, diabetus melitus serta pola hidup yang lain misalnya konsumsi alkohol, olah raga dan lain-lain. 
DAFTAR PUSTAKA

Cahyono, JB. S.B. 2008. Gaya Hidup dan Penyakit Moderen. Penerbit Kanisius. Yogjakarta

Chang, Tara I., et al. 2013. Risk Factors for ESRD in Individuals With Preserved Estimated GFR With and Without Albuminuria: Results From the Kidney. Early Evaluation Program (KEEP). The National Kidney Foundation, Inc. Published by Elsevier Inc. Diunduh 14 Maret 2016

Delima. 2014. Studi Kasus Kontrol Gagal Ginjal Kronik : Faktor Risiko Penyakit Ginjal KronikStudi Kasus Kontrol. Kemenkes RI. Jakarta.

Dinas Kesehatan Propinsi Jawa Tengah. 2008. Profil Kesehatan Propinsi Jawa tengah Tahun 2008.

IRR (Indonesian Renal Registry). 2011. Report of Indonesian Renal Registry. Edisi IV. Jakarta.

Mahon A., Karon Jenkins, dan Lisa Burnapp. 2013. Oxford Hanbook of Renal Nursing.Oxford University Press. United Kingdom.

McKercher, C. M., et al. 2013. "Psychosocial factors in adults with chronic kidney disease: characteristics of pilot participants in the Tasmanian Chronic Kidney Disease Study". BioMed Centrall (BMC) Nephrology.14:83. Diunduh 18 Maret 2016
Oja, Simo S. dan Pirjo Saransaari. 2006. Taurine: Advances Experimental Medicine and Biology. Springe Science and Bussines Media. USA

Restianika, N. 2014. Faktor Yang Berhubungan Dengan Kejadian Gagal Ginjal Kronik Pada Pasien Rawat Inap Ruang Penyakit Dalam Di RSUD dr.Soeroto Kabupaten Ngawi. Skripsi. Universitas Jember. Diunduh 18 Maret 2016.

Smeltzer, S. C. dan B. G. Bare. 2010. Brunner and Suddarth's Text Book of Medical Surgical Nursing. $10^{\text {th }}$ edition. Lippincot and Williams.

William, Linda S. and Paula D.Hopper. 2003. Understanding Medical Surgical Nursing, $2^{\text {nd }}$ edition. Davis Company, Philadephia. USA

\footnotetext{
${ }^{1}$ Dosen Akper Panti Kosala Surakarta

${ }^{2}$ Dosen Akper Panti Kosala

Surakarta
} 